Acta Universitatis Wratislaviensis No 4001

PRAWO CCCXXXI

Wrocław 2020

https://doi.org/10.19195/0524-4544.331.17

\author{
BOŻENA POPOWSKA
}

ORCID: 0000-0002-7453-6129

Uniwersytet im. Adama Mickiewicza w Poznaniu

bozenapopowska@op.pl

\title{
Niepomijalność standardów „dobrej administracji” w publicznym prawie gospodarczym
}

\begin{abstract}
Abstrakt: Ustawa z dnia 6 marca 2018 roku Prawo przedsiębiorców zawiera katalog przepisów o charakterze głównie procesowym, nawiązujących do zasad ogólnych, unormowanych w kodeksie postępowania administracyjnego, traktowanych jako wzorzec „dobrej administracji”. Zamieszczone $\mathrm{w}$ tej ustawie zasady prawa dotyczące działania administracji publicznej mają szerszy zakres stosowania aniżeli sprawy podejmowania, wykonywania i zakończenia działalności gospodarczej. Można je uznać za zasady ogólne (procesowe), to jest doniosłe dla całego porządku publicznego prawa gospodarczego, a nie jedynie w sferze zadań państwa związanych z podejmowaniem, wykonywaniem i zakończeniem działalności gospodarczej.
\end{abstract}

Słowa kluczowe: dobra administracja, Prawo przedsiębiorców, publiczne prawo gospodarcze.

\section{Wprowadzenie — przedmiot, zakres i cel artykułu}

Tytuł konferencji nieodparcie kieruje moje myśli na „dobrą administrację”, to jest działającą według dobrych standardów, określonych przepisami publicznego prawa gospodarczego, adresowanych do organów administracji publicznej. Tytułowe zagadnienie zyskuje na aktualności ${ }^{1} \mathrm{~W}$ związku z wejściem w życie no-

1 Por. B. Popowska, Prawo działalności gospodarczej wobec wymogów dobrej administracji, [w:] Prawo administracyjne wobec współczesnych wyzwań. Księga Jubileuszowa dedykowana Profesorowi Markowi Wierzbowskiemu, red. J. Jagielski et al., Warszawa 2018, s. 175-182. W tym artykule analizowane są przepisy ustawy z dnia 2 lipca 2004 roku o swobodzie działalności gospodarczej (tekst jedn. Dz.U. z 2007 r. Nr 155, poz. 1095 ze zm.; dalej: u.s.d.g.). 
wej ustawy normującej publicznoprawne zagadnienia działalności gospodarczej. Chodzi o ustawę z dnia 6 marca 2018 roku Prawo przedsiębiorców (dalej: Prawo przedsiębiorców, także: ustawa) ${ }^{2}$. Ustawa ta w niespotykanym wcześniej szerokim zakresie formułuje zasady prawa związane z działalnością gospodarczą, z których część odnosi się do podmiotów władzy publicznej. Zasady adresowane do organów dotyczą głównie prowadzenia postępowania. Koncentrując się na wskazanych w ustawie standardach działania administracji w sferze gospodarki, artykuł włącza się w procesowy nurt badań nauki publicznego prawa gospodarczego, korzystając z dorobku nauki prawa administracyjnego, zwłaszcza procesowego.

W polskiej teorii prawa wyróżnia się pięć sposobów używania wyrażenia „standard prawny”3. W pierwszym znaczeniu jest to reguła prawna o określonych $\mathrm{cechach}^{4}$, w drugim - klauzula generalna, w trzecim — ocena rozumiana jako wyrażenie oceniające, w czwartym — ogólna zasada prawna, a w piątym — standard technologiczny 5 .

Obok tych pięciu podstawowych znaczeń w polskim języku prawniczym standard wiążący prawnie występuje także w znaczeniu nadanym mu przez Ronalda Dworkina, który tę nazwę traktował jako denotującą wszystkie elementy obowiązującego porządku prawnego, zaliczając do jej zakresu przede wszystkim reguły (normy zwykłe), zasady i dyrektywy polityczne (policies) ${ }^{6}$. Z uwagi na to, że teoria zasad prawa Dworkina jest jednym z fundamentów współczesnego definiowania zasad prawa ${ }^{7}$, również to znaczenie ,przebija” — często w sposób nieuświadomiony - w nauce prawa, w kórej zasada prawa to po prostu jeden ze standardów obowiązujących prawnie. Nie w tym ostatnim znaczeniu sięgam jednak po pojęcie „standardu”. Używam go jako wskazującego na pewien wzorzec powszechnie akceptowanego zachowania w danej sferze. Jeżeli ten aksjologicznie warunkowany wzorzec zostanie uznany przez prawodawcę za wyjątkowo istotny,

2 Dz.U. z 2018 r. poz. 646 ze zm.

3 J. Wróblewski, Teoretyczne zagadnienia standardów w prawodawstwie w stosowaniu pra$w a$, „Ruch Prawniczy, Ekonomiczny i Socjologiczny” 1989, nr 3, s. 1.

4 Wskazywane jako „reguły bardziej nieokreślone, ogólne, mniej skonkretyzowane niż inne reguły, i pod tym względem zbliżające się [wyr. - B.P.] do rozpowszechnionych charakterystyk zasad prawa" - ibidem, s. 2.

5 Standard w piątym podstawowym znaczeniu „w sposób opisowy ustala model zachowania lub jego wytworu. [...] jest używany we wszelkiej standaryzacji, która formułuje »normy« określonych przedmiotów przez charakterystykę ilościową określonych cech" - ibidem, s. 5-6. Zob. też A. Michalska, Prawne i ekonomiczne aspekty stanowienia i realizacji norm technicznych, „Studia Prawnicze" 1972, z. 32, s. 15, 17.

${ }^{6}$ Zob. zwłaszcza ,they make use of standards that do not function as rules, but operate differently as principles, policies, and other sorts of standards [wyr. - B.P]" - R. Dworkin, The model of rules, [w:] Philosophy of Law, red. J. Feinberg, H. Gross, Belmont 1986, s. 153.

7 Zob. np. M. Kordela, Zasady jako wiążace standardy, [w:] eadem, Zasady prawa. Studium teoretycznoprawne, Poznań 2012, s. 44-61. 
to albo doń odsyła, albo go pozytywizuje pod postacią na przykład zasad prawa ${ }^{8}$. Ten ostatni przypadek ma miejsce właśnie w analizowanej materii artykułu9 .

Zwrócenie uwagi na przedmiot regulacji ustawy Prawo przedsiębiorców, jakim jest działalność gospodarcza, nie oznacza, że w rozważaniach można pominąć rolę administracji w gospodarce, poza typowymi stosunkami związanymi z podejmowaniem, wykonywaniem i zakończeniem działalności gospodarczej, jak na przykład w zakresie pomocy publicznej czy ochrony mienia państwowego. Także w tych sferach oczekiwać należy dobrych standardów jakości działań (postępowania) administracji publicznej. Stąd podstawowe pytanie, jakie jawi się w tych rozważaniach, to czy zasady (bądź niektóre zasady) prawa ujęte w ustawie Prawo przedsiębiorców, adresowane do podmiotów władzy, mają generalne zastosowanie w stosunkach między organami administracji publicznej i przedsiębiorcami.

W opracowaniu wskażę na różne zadania (funkcje) administracji publicznej w dziedzinie gospodarki i związane z nimi procedury realizacji zadań (punkt 1); na znaczenie ustawy Prawo przedsiębiorców w zbiorze norm (dziale) publicznego prawa gospodarczego (punkt 2) oraz na niektóre ujęte w Prawie przedsiębiorców zasady prawa określające standardy działania administracji (punkt 3).

Prowadzone rozważania będą podstawą do zastanowienia się, czy tendencji regulowania przez przepisy publicznego prawa gospodarczego coraz to nowych aspektów życia gospodarczego, i to w wielu zakresach bardzo szczegółowo (specjalizacji przepisów tego działu prawa), nie towarzyszy tendencja silniejszego związania administracji działającej w tej sferze zasadami „dobrej administracji”, po to, by realizować wartości, na których ten dział prawa jest kształtowany. Za taką tezą, nawiązującą do tytułowej ,niepomijalności standardów dobrej administracji”, przemawiałoby między innymi ustalenie uniwersalnego charakteru zasad prawa adresowanych do organów administracji w ustawie Prawo przedsiębiorców. Ustalenia w rozważanym tu zakresie wpisują się w nurt rozważań odpowiadających na postulat Teresy Rabskiej „uporządkowania stanu prawa” przez opracowanie „tzw. zasad ogólnych odnoszących się do całości publicznego prawa gospodarczego" 10 . Dodać należy, że wskazywany przez T. Rabską kierunek badań zajmuje poczesne miejsce w doktrynie publicznego prawa gospodarczego ${ }^{11}$.

8 M. Kordela, Zasady prawa jako normatywna postać wartości, „Ruch Prawniczy, Ekonomiczny i Socjologiczny" 2006, nr 1, s. 41-42.

$9 \mathrm{Na}$ temat przenikania ocen i norm w porządku zasad prawa publicznego prawa gospodarczego zob. M. Kordela, Zasady publicznego prawa gospodarczego. Próba konceptualizacji, [w:] Państwo a gospodarka. Zasady - instytucje - procedury. Księga Jubileuszowa dedykowana Profesor Bożenie Popowskiej, red. P. Lissoń, M. Strzelbicki, Poznań 2020, s. 57-67.

10 T. Rabska, Publiczne prawo gospodarcze - na przełomie?, [w:] Nowe problemy badawcze w teorii publicznego prawa gospodarczego ( $z$ uwzględnieniem samorzadu terytorialnego), red. L. Kieres, Wrocław 2010, s. 249.

11 W tym nurcie badań uwzględnić należy także wcześniejsze opracowania dotyczące „zasad podstawowych" - A. Chełmoński, L. Kieres, [w:] Administracyjne prawo gospodarcze, red. 
Omawiana ustawa zapewne będzie miała wpływ na kolejne prace poświęcone syntezie i systematyzacji teoretycznej zasad prawa ważkich dla działu publicznego prawa gospodarczego.

W tym kontekście niniejszy artykuł ma charakter fragmentaryczny; koncentruje się na uregulowaniu w ustawie standardów działania organów władzy ujętych w formę zasad prawa. Tekst nawiązuje do opublikowanych prac dotyczących zasad podejmowania i wykonywania działalności gospodarczej sformułowanych w Prawie przedsiębiorców ${ }^{12}$ oraz do wcześniejszego opracowania autorki, w którym w kontekście zasad „dobrej administracji” analizie poddane zostały przepisy nieobowiązującej już ustawy o swobodzie działalności gospodarczej ${ }^{13}$.

\section{Zadania (funkcje) administracji publicznej w dziedzinie gospodarki i procedury służące ich realizacji}

W rozważaniach na temat dobrych standardów jakości działań administracji publicznej w sferze gospodarki uwzględnić należy fakt, że przedmiotem regulacji publicznego prawa gospodarczego są różne zadania (funkcje) państwa w sferze i wobec gospodarki ${ }^{14}$, których istota sprowadza się do ingerencji w funkcjonowanie rynku ${ }^{15}$. Poza działaniami ograniczającymi - ze względu na ważny interes

A. Borkowski et al., Wrocław 2009, rozdz. I, s. 11-69; ,zasad prawa gospodarczego" - K. Strzyczkowski, Prawo gospodarcze publiczne, Warszawa 2011, s. 79-115; oraz „zasad ogólnych” J. Grabowski, Zasady ogólne publicznego prawa gospodarczego, rozdz. III, [w:] System Prawa Administracyjnego, t. 8a. Publiczne prawo gospodarcze, red. R. Hauser, Z. Niewiadomski, A. Wróbel, Warszawa 2018, s. 459-542. Dodać należy, że autorzy tych opracowań w różny sposób ujmują tytułową kategorię ,zasad”.

12 M. Zdyb, Podstawowe zasady (standardy) ładu gospodarczego w świetle ustawy z 6.3. 2018 r. - Prawo przedsiębiorców, „Monitor Prawniczy” 2018, nr 13, dodatek, s. 5-13; K. Kokocińska, [w:] Konstytucja biznesu. Komentarz, red. M. Wierzbowski, Warszawa 2019, s. 89-105; L. Bielecki, [w:] Konstytucja biznesu..., s. 148-155; K. Kokocińska, Gwarancyjny charakter zasad prawa (rozważania na tle ustawy Prawo przedsiębiorców) [w druku]; B. Popowska, Zasady postępowania w sprawach z zakresu działalności gospodarczej unormowane w ustawie Prawo przedsiębiorców, „Ruch Prawniczy, Ekonomiczny i Socjologiczny” 2018, nr 4, s. 28-40.

13 Zob. przyp. 1.

14 T. Rabska, Jakie prawo gospodarcze? - próba odpowiedzi, ,Ruch Prawniczy, Ekonomiczny i Socjologiczny" 1993, nr 1, s. 21. Na temat funkcji zob. B. Popowska, Klasyfikacja funkcji administracji w nauce publicznego prawa gospodarczego, [w:] Funkcje współczesnej administracji gospodarczej, red. B. Popowska, Poznań 2006, s. 61-86.

15 Por. definicje publicznego prawa gospodarczego przedstawione przez C. Kosikowskiego, Publiczne prawo gospodarcze Polski i Unii Europejskiej, Warszawa 2006, s. 36-38. 
publiczny - gwarantowaną konstytucyjnie ,wolność gospodarczą ${ }^{16}$ wiele zadań administracji publicznej ukierunkowanych jest na realizację celów związanych z całą gospodarką lub jej segmentem. Chodzi o takie zadania, jak: organizacja rozwoju życia gospodarczego w różnych jego aspektach, na przykład innowacyjności, w tym elektromobilności ${ }^{17}$; wspieranie przedsiębiorczości prywatnej poprzez udzielanie pomocy publicznej ${ }^{18}$; ochrona strategicznych branż gospodarki, takich jak wytwarzanie energii elektrycznej ${ }^{19}$. Także w tych zakresach w wielu przypadkach adresatem działań administracji jest przedsiębiorca (publiczny bądź prywatny), tyle że podstawowym motywem podejmowania zadań w tych obszarach (ingerencji w sferze gospodarki) jest określony cel publiczny, a nie interes poszczególnego przedsiębiorcy ${ }^{20}$. Uwaga ta dotyczy również procedur zawierania przez administrację umów z przedsiębiorcami ${ }^{21}$.

O celach i cechach interwencji państwa w gospodarce świadczyć może, coraz częściej stosowane, określenie ich jako „powinności publiczne”22. Już samo to miano sugeruje konieczność spełniania przez administrację, jako wykonawcę polityki państwa w sferze gospodarki, standardów (wymogów) „dobrej administracji”, formułowanych w nauce prawa administracyjnego jako zasada (zasady) dobrej administracji ${ }^{23}$. Treść tych zasad odczytać można z norm prawa ustrojowego i materialnego, jednak przeważa ich ujmowanie w kontekście gwarancji proceduralnych ${ }^{24}$. Jak już zaznaczano, także w tym artykule przyjęto procesowoprawną optykę analizy przepisów ustawy.

16 Zob. art. 20 i 22 Konstytucji Rzeczypospolitej Polskiej z dnia 2 kwietnia 1997 roku (Dz.U. Nr 78 ze zm.; dalej: Konstytucja RP).

17 Zob. ustawa z dnia 30 maja 2008 roku o niektórych formach wspierania innowacyjności (tekst jedn. Dz.U. z 2018 r. poz. 141 ze zm.), a także ustawa z dnia 11 stycznia 2018 roku o elektromobilności i paliwach alternatywnych (Dz.U. poz. 317 ze zm.; dalej: ustawa o elektromobilności).

18 Ustawa z dnia 6 grudnia 2006 roku o zasadach prowadzenia polityki rozwoju (tekst jedn. Dz.U. z 2018 r. poz. 1307 ze zm.).

19 Ustawa z dnia 24 lipca 2015 roku o kontroli niektórych inwestycji (Dz.U. z 2016 r. poz. 980 ze zm.; dalej: ustawa o kontroli niektórych inwestycji).

${ }^{20}$ Przykładem „włączenia” przedsiębiorców do realizacji celów publicznych polegających na rozwoju infrastruktury paliw alternatywnych może być instytucja wyznaczenia przez prezes URE — w drodze decyzji administracyjnej — operatora ogólnodostępnej stacji ładowania (art. 65 ust. 2 ustawy o elektromobilności). Zob. P. Lissoń, Zadania gmin w dziedzinie elektromobilności, [w:] Prawne i ekonomiczne aspekty rozwoju elektromobilności, red. K. Kokocińska, J. Kola, Warszawa 2019, rozdz. IV, s. 53-85. Zob. także w tej monografii B. Popowska, Obowiązi prawne podmiotów publicznych w zakresie elektromobilności. Możliwości zastosowania PPP, rozdz. VIII, s. 145-160.

21 Zob. B. Popowska, Ochrona interesu publicznego w regulacjach partnerstwa publiczno-prywatnego w Polsce, [w:] Republicyzacja zadań publicznych, red. M. Szewczyk et al., Poznań 2018, s. 51-72.

22 C. Kosikowski, op. cit., m.in. s. 41; L. Kieres, Podmioty petniace funkcje administracji gospodarczej w Polsce, rozdz. IV, Ustrój i zadania administracji gospodarczej, [w:] System Prawa Administracyjnego, t. 8a, s. 579.

23 J. Zimmermann, Prawo administracyjne, Warszawa 2016, s. 168-171.

24 M. Princ, Standardy dobrej administracji, Poznań 2017, s. 17. 
W płaszczyźnie polskiego prawa wymogi „dobrej administracji” wyrażają głównie zasady ogólne postępowania administracyjnego zawarte w k.p.a. ${ }^{25} \mathrm{Za}-$ znaczyć przy tym należy, że treścią wykraczają one poza kwestie procesowe ${ }^{26}$. Zasady ogólne k.p.a. są normatywną bazą do rozumienia „dobrej administracji” w tym opracowaniu.

Mając na uwadze to założenie, podkreślić należy, że ze względu na różne funkcje i zadania administracji w gospodarce model postępowania jurysdykcyjnego unormowanego w k.p.a. nie jest powszechnie stosowany w sferze stosunków normowanych publicznym prawem gospodarczym ${ }^{27}$. Odrębną kwestią jest stosowanie zasad ogólnych k.p.a. W myśl teorii prawa administracyjnego procesowego zasady te, a przynajmniej znaczna ich część, powinny być respektowane przez organy administracji publicznej w każdej ich działalności, także poza postępowaniem administracyjnym, zmierzającym do wydania decyzji ${ }^{28}$. Z uwagi jednak na specyfikę wielu postępowań unormowanych przepisami publicznego prawa gospodarczego, zwłaszcza ukierunkowanych na realizację celów związanych z całą gospodarką lub jej segmentem, nie wszystkie zasady ogólne k.p.a. mogą znaleźć $\mathrm{w}$ nich zastosowanie ${ }^{29}$. Z drugiej strony przedsiębiorcy w relacjach $\mathrm{z}$ administracją oczekują od niej uwzględnienia szczególnych warunków działania na rynku.

Prawodawca, normując publicznoprawne stosunki gospodarcze, dostrzega ten dylemat, wprowadzając do porządku prawnego (w coraz szerszym zakresie) zasady prawa, które dotyczą sposobów (procedur) realizowania zadań publicznych przez administrację, w tym standardów „dobrej administracji”. Wskazać należy zwłaszcza na przepisy ustawy Prawo przedsiębiorców ${ }^{30}$, która, poza zasa-

25 Tak Z. Kmieciak, Idea sprawiedliwości proceduralnej w prawie administracyjnym (założenia teoretyczne i doświadczenia praktyki), „Państwo i Prawo” 1994, nr 10, s. 57, 63. Szerzej na temat podstaw obowiązywania zasady dobrej administracji w UE i krajowym porządku prawnym zob. B. Popowska, Prawo działalności gospodarczej..., s. 176-177. W doktrynie prezentowane jest stanowisko, że zasada dobrej administracji jest zasadą ogólną, tak między innymi E. Olejniczak-Szałowska, [w:] Prawo administracyjne. Pojęcia, instytucje, zasady w teorii i orzecznictwie, red. M. Stahl et al., Warszawa 2013, s. 196 n.

26 Zob. J. Zimmermann, op. cit., s. 171.

27 Szerzej zob. B. Popowska, Nowe procedury publicznego prawa gospodarczego. Problem gwarancji procesowych dla podmiotów działalności gospodarczej, [w:] Praworzadność, decentralizacja, przedsiębiorczość. Księga jubileuszowa Profesora Leona Kieresa, red. K. Kiczka, T. Kocowski, W. Małecki, Wrocław 2018, s. 593-608.

28 Zob. J. Zimmermann, op. cit., s. 171. Por. uwagi do przyp. 18.

29 Przykładem może być postępowanie unormowane przepisami ustawy o kontroli niektórych inwestycji (przyp. 10), w którym jedyną przesłanką (poza względami formalnymi) braną pod uwagę przy rozstrzyganiu przez właściwy organ o zgłoszeniu „sprzeciwu” (w formie decyzji administracyjnej) jest stypizowany interes publiczny; ratio legis tego unormowania jest nie do pogodzenia $\mathrm{z}$ unormowaną $\mathrm{w}$ art. 7 k.p.a. zasadą uwzględniania interesu społecznego i słusznego interesu strony (art. 7).

30 Także w poprzednio obowiązujących ustawach o podobnym przedmiocie normowania część ich przepisów określała zasady ogólne; w ustawie z dnia 19 listopada 1999 roku Prawo działalności gospodarczej (Dz.U. Nr 101, poz. 1178 ze zm.; dalej: p.d.g.), rozdz. 1 i 2 oraz w u.s.d.g. — rozdz. 1 i 2. 
dami treściowo tożsamymi z zasadami ogólnymi k.p.a., określa również zasady swoiste dla stosunków publicznoprawnych w gospodarce. W uzasadnieniu projektu ustawy wskazuje się na związek ujętych w niej zasad z ustrojem społecznej gospodarki rynkowej określonym w Konstytucji RP i opisuje się je jako „zasady ogólne prawa gospodarczego"31.

Określenie wymienionych zasad jako „zasad ogólnych” można odczytać jako przypisanie im cechy uniwersalności w sferze stosunków gospodarczych. Ten aspekt charakterystyki zasad prawa ujętych w ustawie Prawo przedsiębiorców, $\mathrm{z}$ akcentem na zasady procesowe, jest $\mathrm{w}$ tym artykule szczególnie podkreślany. Wymaga to zwrócenia uwagi na znaczenie ustawy w porządku publicznego prawa gospodarczego.

\section{Znaczenie ustawy Prawo przedsiębiorców w systemie publicznego prawa gospodarczego}

O znaczącym miejscu ustawy Prawo przedsiębiorców w systemie publicznego prawa gospodarczego ${ }^{32}$ przesądza przedmiot regulacji tej ustawy, a podkreśla użycie w tytule ustawy pojęcia „Prawo” oraz zamieszczona w ustawie preambuła.

Znaczenie użycia w tytule ustawy terminu „Prawo” wydaje się oczywiste w świetle przepisów rozporządzenia w sprawie „Zasad techniki prawodawczej”33 — wskazuje ono na uregulowanie w ustawie kwestii zasadniczych w danej dziedzinie spraw, bo związanych z konstytucyjną wolnością działalności gospodarczej.

Również zamieszczenie preambuły odwołującej się do Konstytucji RP podnosi rangę ustawy. Zauważyć przy tym należy, że wskazane w preambule, z powołaniem się na zasady konstytucyjne, cele ustawodawcy i preferowane wartości wykraczają poza kwestie związane stricte z wolnością działalności gospodarczej. Uwaga ta nawiązuje do wąsko określonego zakresu regulacji ustawy (art. 1). W tym kontekście powrócić można do pytania o znaczenie dla całego porządku publicznego prawa gospodarczego zasad prawa ujętych w ustawie, zwłaszcza będących tu przedmiotem zainteresowania zasad prawa adresowanych do administracji publicznej.

W art. 1 ustawy wskazuje się na dwa zakresy regulacji: „podejmowanie, wykonywanie i zakończenie działalności gospodarczej na terytorium Rzeczypospo-

31 Uzasadnienie projektu ustawy, druk sejmowy nr 2501 Sejmu VIII kadencji, dalej: uzasadnienie projektu, m.in. s. 1, 7.

$32 \mathrm{~W}$ doktrynie ustawę Prawo przedsiębiorców uznaje się za podstawowe źródło publicznego prawa gospodarczego, tak między innymi M. Zdyb, op. cit., s. 5; K. Kokocińska, [w:] Konstytucja biznesu..., s. 29.

33 Rozporządzenie Prezesa Rady Ministrów z dnia 20 czerwca 2002 roku w sprawie „Zasad techniki prawodawczej” (Dz.U. z 2002 r. Nr 100, poz. 908, § 9). 
litej Polskiej” oraz „zadania organów w tym zakresie”. Ujęte w ustawie zasady prawa związane są z obydwoma zakresami.

W pierwszym zakresie regulacji chodzi w istocie o określenie statusu prawnego przedsiębiorców poprzez normatywne rozwinięcie treści konstytucyjnej zasady wolności gospodarczej (art. 20 Konstytucji RP), określenie istoty materialnoprawnej tej zasady oraz gwarancji procesowych, które ona determinuje (zwłaszcza art. 2 i 8), a także zdefiniowanie podstawowych pojęć i instytucji prawnych związanych z działalnością gospodarczą (zwłaszcza art. 3 i art. 4 ust. 1 i 2).

Przepisy zamieszczone $\mathrm{w}$ drugim obszarze regulacji ustawy określają zadania organów władzy publicznej związane bezpośrednio z podejmowaniem, wykonywaniem i zakończeniem działalności gospodarczej, w tym polegające na reglamentacji działalności gospodarczej (rozdz. 4) i jej kontroli (rozdz. 5). Dodać należy, że Prawo przedsiębiorców nie zawiera przepisów, które wyznaczałyby administracji zadania wykraczające poza sferę podejmowania, wykonywania i zakończenia działalności gospodarczej, tak jak to czyniły poprzednio obowiązujące ustawy p.d.g. ${ }^{34}$ i u.s.d.g. ${ }^{35}$ Nie znaczy to jednak, że ujęte w ustawie zasady prawa wiążące organy władzy w relacjach z przedsiębiorcami znajdować mogą zastosowanie tylko w sprawach stricte związanych z działalnością gospodarczą, to znaczy z zakresem zadań organów unormowanych wprost w tej ustawie. Wniosek taki uzasadnia przede wszystkim treść (sposób sformułowania) samych zasad, o czym piszę w następnym punkcie. Na możliwość szerszego ich zastosowania wskazuje także treść preambuły, która podkreśla związek zasad ujętych w ustawie $\mathrm{z}$ mającymi uniwersalne znaczenie zasadami konstytucyjnymi ${ }^{36}$.

34 Zob. zwłaszcza odrębny rozdział p.d.g. zatytułowany „Zadania organów administracji rządowej i organów jednostek samorządu terytorialnego w zakresie działalności gospodarczej" oraz opracowania w tym zakresie opublikowane w „Ruchu Prawniczym, Ekonomiczny, i Socjologicznym" 2002, nr 2 - T. Rabska, Zadania administracji publicznej w działalności gospodarczej (problem zakresu obowiązywania prawa działalności gospodarczej), s. 137-152; oraz B. Popowska, Wspieranie małych i średnich przedsiębiorców - charakterystyka przepisów Prawa działalności gospodarczej $i$ ich realizacja, s. 123-136.

35 Zob. zwłaszcza art. 7 określający zasadę udzielania pomocy publicznej przedsiębiorcom przez państwo oraz art. 8 określający zasadę wspierania rozwoju przedsiębiorczości. Na temat znaczenia tych zasad w kontekście zadań państwa w gospodarce zob. m.in. T. Rabska, „Norma zadaniowa" w świetle publicznego prawa gospodarczego, [w:] W poszukiwaniu dobra wspólnego. Ksiegga jubileuszowa Profesora Macieja Zielińskiego, red. A. Chodun, S. Czepita, Szczecin 2010, s. 670; K. Kokocińska, Prawne aspekty wspierania rozwoju przedsiębiorczości - ustawa o swobodzie działalności gospodarczej oraz ustawy ustrojowo-kompetencyjne, „Ruch Prawniczy, Ekonomiczny i Socjologiczny" 2005, nr 4, s. 37-50.

36 Z. Ziemski uważa takie ujęcie preambuły za jedną z formalnych przesłanek uznania norm ustawy „za zasadnicze”; idem, Zasady ogólne prawa administracyjnego, Poznań 1989, s. 74-105. W doktrynie publicznego prawa gospodarczego wskazuje się, że zasady zamieszczone w preambule Prawa przedsiębiorców mają normatywny charakter i mogą być podstawą praw i obowiązków; tak między innymi M. Zdyb, op. cit., s. 5; K. Kokocińska, Wspieranie rozwoju działalności gospodarczej w ujęciu zasad i wartości, „Ruch Prawniczy, Ekonomiczny i Socjologiczny” 2018, nr 4, s. 41-43. 
W preambule, powołując się na konstytucyjne zasady ${ }^{37}$, wskazuje się na wartości, którymi kieruje się prawodawca, normując stosunki prawne między podmiotami władzy i przedsiębiorcami w związku z działalnością gospodarczą. Są to „ochrona i wspieranie wolności działalności gospodarczej”, „zagwarantowanie praw przedsiębiorców" przy uwzględnieniu szerszego spektrum interesów publicznych, jakimi są ,zapewnienie ciągłego rozwoju działalności gospodarczej ${ }^{38}$ w warunkach wolnej konkurencji”. Preambuła powołuje się także na inne zasady konstytucyjne: ,praworządności, pewności prawa, niedyskryminacji oraz zrównoważonego rozwoju". Zasady w niej ujęte są jasnymi podstawami aksjologicznymi interpretacji obowiązków organów władzy, jak i praw oraz obowiązków przedsiębiorców. Dotyczy to także zasad prawa ujętych w przepisach merytorycznych.

\section{Zasada zaufania do przedsiębiorców i inne zasady ogólne publicznego prawa gospodarczego}

W nawiązaniu do przedmiotu regulacji ustawy i jej struktury stwierdzić należy, że normy określające konkretne obowiązki organów administracji publicznej, znajdujące wyraz w kompetencjach do działań prawnych oraz we wskazanych czynnościach materialno-technicznych, zamieszczone są głównie w rozdziale czwartym o reglamentacji działalności gospodarczej (te pierwsze) i rozdziale piątym o ograniczeniach kontroli działalności gospodarczej (te drugie). Zasady prawa ujęte są natomiast w rozdziale pierwszym — „Przepisy ogólne” i w rozdziale trzecim - „Załatwianie spraw z zakresu działalności gospodarczej”.

W doktrynie publicznego prawa gospodarczego wskazuje się na dwa zespoły zasad prawa zamieszczonych w ustawie: dotyczące przedsiębiorców oraz dotyczące organów władzy ${ }^{39}$. W tym opracowaniu uwaga skupiona jest przede wszystkim na zasadach prawa odnośnie do działań administracji publicznej ${ }^{40}$.

Jak wskazywano, zasady zawarte w ustawie Prawo przedsiębiorców były już analizowane $\mathrm{w}$ doktrynie, także $\mathrm{w}$ formie komentarza do tej ustawy ${ }^{41}$. W tym opracowaniu nie chodzi zatem o charakterystykę zasad prawa, ale o wskazanie tych zasad ujętych w ustawie, które w swej treści określają standardy działań admi-

37 Wyrażone wprost lub wywodzone z zamieszczonej w art. 2 Konstytucji zasady demokratycznego państwa prawnego.

38 Zob. rozważania K. Kokocińskiej na temat „rozwoju działalności gospodarczej” jako zadania państwa w świetle przepisów ustawy Prawo przedsiębiorców; eadem, Wspieranie rozwoju działalności gospodarczej..., s. 41-43.

39 K. Kokocińska, [w:] Konstytucja biznesu..., s. 31 i wskazana literatura.

40 Pełny katalog zasad prawa unormowanych w ustawie Prawo przedsiębiorców przedstawia M. Chołodecki, Zasady publicznego prawa gospodarczego, „Prawo” 329, 2019, s. 34-39.

${ }^{41}$ Zob. przyp. 5. 
nistracji bez przedmiotowych ograniczeń do kwestii podejmowania, wykonywania i zakończenia działalności gospodarczej. Te elementy charakterystyki zasad z uwzględnieniem rangi ustawy w porządku publicznego prawa gospodarczego mogą wskazywać na podobną ich rolę w tym dziale prawa do roli przypisywanej zasadom ogólnym k.p.a. ${ }^{42}$ Zamieszczenie w Prawie przedsiębiorców zasad o takim charakterze jest, moim zdaniem, właściwym kierunkiem regulacji publicznego prawa gospodarczego.

W analizowanym zakresie uwagę zwraca przede wszystkim zasada, która stanowi nowość w porządku prawnym RP; jest związana ze sferą gospodarki, a ściślej — z sytuacją przedsiębiorcy w relacjach z administracją publiczną. Chodzi o zasadę zaufania do przedsiębiorcy (domniemania uczciwości przedsiębiorcy ${ }^{43}$; art. 10 ust. 1), która poza znaczeniem dla toku postępowania ma też wpływ na stosowanie prawa materialnego. Nakazuje ona organom władzy publicznej kierować się „w swoich działaniach” założeniem, że przedsiębiorca działa zgodnie z prawem, uczciwie oraz z poszanowaniem dobrych obyczajów. Treściowo zasada ta jest związana $\mathrm{z}$ art. 9 ustawy określającym pozytywny wzorzec przedsiębiorcy $^{44}$. Zasada zaufania do przedsiębiorcy ma zatem silne uzasadnienie aksjologiczne. Należy do kategorii nakazów optymalizacyjnych. Artykuł 10 nie wskazuje wyraźnie, jaki jest jego zakres zastosowania, użycie natomiast sformułowania „w działaniach” pozwala na szerokie stosowanie zawartej w nim normy, także poza stosunkami związanymi z podejmowaniem, wykonywaniem i zakończeniem działalności gospodarczej. Taka interpretacja znajduje uzasadnienie w celach, jakim ma służyć ustawa, określonych w jej preambule. Zasada zaufania do przedsiębiorcy zasługuje zatem na uznanie jej za zasadę prawa całego działu, jakim jest publiczne prawo gospodarcze.

Rozważając z interesującego tu punktu widzenia znaczenie pozostałych zasad prawa określających standardy działania administracji ujętych w Prawie przedsiębiorców, zwrócić należy uwagę, że większość spośród nich nie wprowadza do porządku prawnego istotnie nowych treści. Ich główna treść albo pokrywa się, albo jest zbieżna $\mathrm{z}$ treścią określonych zasad ogólnych k.p.a. Pojawia się zatem pytanie, czy zawarte w Prawie przedsiębiorców zasady, mimo ich zbieżności treściowej z zasadami ogólnymi k.p.a., można traktować jako za zasady publicznego prawa gospodarczego.

42 J.P. Tarno, Funkcje zasad ogólnych postępowania administracyjnego, rozdz. 1.3, [w:] Zasady ogólne postępowania administracyjnego, t. 2, cz. 2, red. G. Łaszczyca, A. Matan, Warszawa 2018, s. 57-71.

43 Wprowadzenie zasady zaufania do przedsiębiorcy do porządku prawnego jest reakcją na (często) niezbyt przychylne przedsiębiorcom nastawienie organów władzy, które może wynikać między innymi ze zdarzających się faktów naruszania przez przedsiębiorców prawa.

44 W myśl art. 9 ustawy „Przedsiębiorca wykonuje działalność gospodarczą zgodnie z zasadami uczciwej konkurencji, poszanowaniem dobrych obyczajów oraz słusznych interesów innych przedsiębiorców i konsumentów, a także poszanowania oraz ochrony praw i wolności człowieka". 
Odpowiedź wydaje się prosta - skoro zamieszczone są one w podstawowej ustawie, w zbiorze przepisów publicznego prawa gospodarczego, to - jako wypowiedź dyrektywalna ${ }^{45}$ - zyskują status zasad prawa tego działu prawa. Dotyczy to także zamieszczonej w ustawie zasady „pewności stosowania prawa”, której ujęcie słowne $\mathrm{w}$ art. 14 jest tożsame $\mathrm{z}$ treścią zasady zawartej $\mathrm{w}$ art. $8 \S 2$ k.p.a., określanej w łączności z normą zawartą w art. $8 \S 1$ k.p.a. jako zasada pogłębiania zaufania uczestników postępowania do władzy publicznej. Podkreślić jednak trzeba, że większość zasad prawa zamieszczonych w analizowanej ustawie wiąże (wyraźnie albo poprzez kontekst) dyspozycję normy kierowanej do podmiotu władzy z adresatami konstytucyjnej wolności działalności gospodarczej, czyli przedsiębiorcami (wyraźnie: art. 10 ust. 2, art. 11, art. 12, art. 15, art. 28, art. 30; poprzez kontekst: art. 27, art. 32). Dzięki temu zabiegowi legislacyjnemu można mówić o podobieństwie takich zasad prawa unormowanych w k.p.a. i ustawie, a nie o ich tożsamości. Nie zmienia to faktu, że istota większości zasad prawa zamieszczonych w Prawie przedsiębiorców jest taka jak odpowiednich zasad ogólnych k.p.a.; te zaś są wzorcem „dobrej administracji”. Teza ta znajduje odzwierciedlenie w tytule tego artykułu.

Nawiązując do tej tezy, w pierwszej kolejności można wymienić unormowaną w Prawie przedsiębiorców zasadę prawa, która przede wszystkim wpływa na przebieg postępowania - jest to zasada szybkiego i wnikliwego działania organów (art. 27) ${ }^{46}$. Jej konkretyzacja znajduje wyraz w przepisach, które precyzują obowiązki organów służące realizacji idei zawartej w wymienionej zasadzie. Chodzi o: zakaz żądania dokumentów w formie oryginałów, jeżeli obowiązek taki nie wynika z przepisów (art. 29); nakaz wyznaczania rozsądnych terminów na dokonanie określonej czynności (art. 30); zakaz żądania dokumentów lub ujawniania danych, jeżeli obowiązek taki nie wynika z przepisów prawa (art. 31). Nie mają one wiernych odpowiedników w k.p.a., choć idee w nich zawarte odnaleźć można w następujących przepisach kodeksu: art. 75 § 2, art. 76, art. 76a, art. $35 \S 2$ i 3. Sformułowanie zasady szybkiego i wnikliwego działania organów wskazuje na jej uniwersalny charakter, co potwierdza ujęcie przepisów określających obowiązki organów w tym zakresie.

Charakter uniwersalny mają także zasady wpływające na wzmocnienie pozycji procesowej przedsiębiorcy: zasada prowadzenia przez organ postępowania w sposób budzący zaufanie przedsiębiorców do władzy publicznej z uwzględnieniem zasad: proporcjonalności, bezstronności i równego traktowania (art. 12) oraz wymieniona wcześniej zasada pewności stosowania prawa (art. 14). Charakter

45 M. Kordela, Zasady prawa..., zwł. s. 25-29.

46 Art. 27, poza nakazem działania „szybko” i ,wnikliwie”, nakazuje organom posługiwanie się „możliwie najprostszymi środkami prowadzącymi do załatwienia spraw”. Takie wytyczne dla organu, bez określenia terminów „załatwienia spraw” (jak w art. 35 § 3 i 3a k.p.a.), uwzględniają różnorodność i specyfikę działań administracji publicznej w sferze gospodarki. 
uniwersalny ma też zasada współdziałania organów (art. 28), zbieżna treściowo z normą zawartą $w$ art. $7 b$ k.p.a.

Ograniczony zakres obowiązywania ustawodawca przewidział natomiast dla następujących zasad: udzielania przedsiębiorcy informacji (art. 15); rozstrzygania wątpliwości faktycznych na korzyść przedsiębiorcy (art. 10 ust. 2) oraz rozstrzygania wątpliwości co do treści normy prawnej na korzyść przedsiębiorcy (art. 11 ust. 1). Wskazany w art. 15 ustawy obowiązek organu odnosi się do informacji o warunkach podejmowania, wykonywania i zakończenia działalności gospodarczej (por. art. 9 k.p.a.). Oba nakazy odnoszące się do rozstrzygania wątpliwości dotyczą z kolei takich postępowań przed organem, których przedmiotem jest nałożenie na przedsiębiorcę obowiązku bądź ograniczenie lub odebranie uprawnienia (por. art. $81 \mathrm{a}$ i art. 7a k.p.a.) ${ }^{47}$.

Wszystkie wymienione zasady adresowane do podmiotów władzy mieszczą się w szeroko rozumianym zwrocie „dobra administracja”, który wiąże się z realizacją celów stawianych administracji ${ }^{48}$. Takie ujęcie pozwala stosować kryterium „dobrej administracji” także poza sferą tradycyjnych, publicznoprawnych relacji władzy wykonawczej z obywatelami lub przedsiębiorcami ${ }^{49}$.

\section{Podsumowanie}

Ustawa Prawo przedsiębiorców jest kolejną ustawą normującą (po zmianie ustroju społeczno-gospodarczego) zasady korzystania z konstytucyjnej wolności gospodarczej. Poza przepisami materialnymi, podkreślającymi związek przepisów ustawy z konstytucyjną zasadą wolności działalności gospodarczej, zawiera ona bogaty katalog przepisów o charakterze głównie procesowym, nawiązujących do zasad ogólnych unormowanych w k.p.a., traktowanych jako wzorzec „,dobrej administracji".

Zamieszczone w ustawie zasady prawa dotyczące działania administracji publicznej mają szerszy zakres stosowania aniżeli sprawy podejmowania, wykonywania i zakończenia działalności gospodarczej. Poza językowym ujęciem tych zasad wniosek ten wzmacnia także treść preambuły do ustawy, która status prawny przedsiębiorcy sytuuje w perspektywie szeroko ujętych zadań państwa w sferze gospodarki, z akcentem na ,zapewnienie ciągłego rozwoju działalności gospodarczej”. Istotne przy tym jest odwoływanie się w preambule do zasad

${ }^{47} \mathrm{Na}$ temat zasad unormowanych w wymienionych przepisach ustawy Prawo przedsiębiorców, w kontekście regulacji k.p.a., zob. B. Adamiak, Zasada domniemania załatwiania spraw indywidualnych na korzyść przedsiębiorcy, [w:] Państwo a gospodarka..., s. 69-80.

48 M. Princ, op. cit., s. 67-73.

49 Nie podważa to tezy, że administracja ma być przede wszystkim „dobra” dla obywatela. Por. J. Zimmerman, op. cit., Warszawa 2016, s. 168. 
konstytucyjnych, przez co akcentuje ona znaczenie odpowiadających im wartości i standardów, których nośnikami są normy merytoryczne ustawy.

W konsekwencji ujęte $\mathrm{w}$ ustawie i uwzględnione w rozważaniach zasady prawa adresowane do administracji o charakterze głównie procesowym uznać można za zasady ogólne (procesowe), to jest doniosłe dla całego porządku publicznego prawa gospodarczego, a nie jedynie w sferze zadań państwa związanych z podejmowaniem, wykonywaniem i zakończeniem działalności gospodarczej.

Podkreślić przy tym należy, że zasady prawa o charakterze głównie procesowym sformułowane w Prawie przedsiębiorców, niezależnie od zbieżności ich treści z treścią zasad ogólnych k.p.a., są zasadami odrębnego działu prawa, jaki tworzą przepisy publicznego prawa gospodarczego. W wielu przepisach podkreślone jest to poprzez związanie danej zasady prawa $\mathrm{z}$ kategorią przedsiębiorców. Nie zmienia to jednak genezy i istoty tych zasad; wpisują się one we wzorzec „dobrej administracji”, jaki w polskim prawie normują przepisy k.p.a.

Ostatnia teza potwierdza trafność tytułu artykułu o niepomijalności „dobrej administracji” w publicznym prawie gospodarczym.

\section{Bibliografia}

Adamiak B., Zasada domniemania załatwiania spraw indywidualnych na korzyść przedsiębiorcy, [w:] Państwo a gospodarka. Zasady — instytucje — procedury. Ksiega Jubileuszowa dedykowana Profesor Bożenie Popowskiej, red. P. Lissoń, M. Strzelbicki, Poznań 2020.

Bielecki L., [w:] Konstytucja biznesu. Komentarz, red. M. Wierzbowski, Warszawa 2019.

Chełmoński A., Kieres L., [w:] Administracyjne prawo gospodarcze, red. A. Borkowski et al., Wrocław 2009.

Chołodecki M., Zasady publicznego prawa gospodarczego, „Prawo” 329, 2019.

Dworkin R., The model of rules, [w:] Philosophy of Law, red. J. Feinberg, H. Gross, Belmont 1986.

Grabowski J., Zasady ogólne publicznego prawa gospodarczego, [w:] System Prawa Administracyjnego, t. 8a. Publiczne prawo gospodarcze, red. R. Hauser, Z. Niewiadomski, A. Wróbel, Warszawa 2018.

Kieres L., Podmioty pelniace funkcje administracji gospodarczej w Polsce, rozdz. IV. Ustrój i zadania administracji gospodarczej, [w:] System Prawa Administracyjnego, t. 8a. Publiczne prawo gospodarcze, red. R. Hauser, Z. Niewiadomski, A. Wróbel, Warszawa 2018.

Kmieciak Z., Idea sprawiedliwości proceduralnej w prawie administracyjnym (założenia teoretyczne i doświadczenia praktyki), „Państwo i Prawo” 1994, nr 10.

Kokocińska K., [w:] Konstytucja biznesu. Komentarz, red. M. Wierzbowski, Warszawa 2019.

Kokocińska K., Gwarancyjny charakter zasad prawa (rozważania na tle ustawy Prawo przedsiębiorców) [w druku].

Kokocińska K., Prawne aspekty wspierania rozwoju przedsiębiorczości - ustawa o swobodzie działalności gospodarczej oraz ustawy ustrojowo-kompetencyjne, „Ruch Prawniczy, Ekonomiczny i Socjologiczny" 2005, nr 4.

Kokocińska K., Wspieranie rozwoju działalności gospodarczej w ujęciu zasad $i$ wartości, „Ruch Prawniczy, Ekonomiczny i Socjologiczny" 2018, nr 4.

Kordela M., Zasady prawa. Studium teoretycznoprawne, Poznań 2012. 
Kordela M., Zasady prawa jako normatywna postać wartości, „Ruch Prawniczy, Ekonomiczny i Socjologiczny" 2006, nr 1.

Kordela M., Zasady publicznego prawa gospodarczego. Próba konceptualizacji, [w:] Państwo a gospodarka. Zasady - instytucje - procedury. Księga Jubileuszowa dedykowana Profesor Bożenie Popowskiej, red. P. Lissoń, M. Strzelbicki, Poznań 2020.

Kosikowski C., Publiczne prawo gospodarcze Polski i Unii Europejskiej, Warszawa 2006.

Lissoń P., Zadania gmin w dziedzinie elektromobilności, [w:] Prawne i ekonomiczne aspekty rozwoju elektromobilności, red. K. Kokocińska, J. Kola, Warszawa 2019.

Michalska A., Prawne i ekonomiczne aspekty stanowienia i realizacji norm technicznych, „Studia Prawnicze" 1972, z. 32.

Olejniczak-Szałowska E., [w:] Prawo administracyjne. Pojęcia, instytucje, zasady w teorii i orzecznictwie, red. M. Stahl et al., Warszawa 2013.

Popowska B., Klasyfikacja funkcji administracji w nauce publicznego prawa gospodarczego, [w:] Funkcje wspótczesnej administracji gospodarczej, red. B. Popowska, Poznań 2006.

Popowska B., Nowe procedury publicznego prawa gospodarczego. Problem gwarancji procesowych dla podmiotów działalności gospodarczej, [w:] Praworządność, decentralizacja, przedsiębiorczość. Księga jubileuszowa Profesora Leona Kieresa, red. K. Kiczka, T. Kocowski, W. Małecki, Wrocław 2018.

Popowska B., Obowiązi prawne podmiotów publicznych w zakresie elektromobilności. Możliwości zastosowania PPP, [w:] Prawne i ekonomiczne aspekty rozwoju elektromobilności, red. K. Kokocińska, J. Kola, Warszawa 2019.

Popowska B., Ochrona interesu publicznego $w$ regulacjach partnerstwa publiczno-prywatnego w Polsce, [w:] Republicyzacja zadań publicznych, red. M. Szewczyk et al., Poznań 2018.

Popowska B., Prawo działalności gospodarczej wobec wymogów dobrej administracji, [w:] Prawo administracyjne wobec wspótczesnych wyzwań. Księga Jubileuszowa dedykowana Profesorowi Markowi Wierzbowskiemu, red. J. Jagielski et al., Warszawa 2018.

Popowska B., Wspieranie matych i średnich przedsiębiorców - charakterystyka przepisów Prawa działalności gospodarczej i ich realizacja, „Ruch Prawniczy, Ekonomiczny i Socjologiczny” $2002, \mathrm{nr} 2$.

Popowska B., Zasady postępowania w sprawach z zakresu działalności gospodarczej unormowane w ustawie Prawo przedsiębiorców, „Ruch Prawniczy, Ekonomiczny i Socjologiczny” 2018, nr 4.

Princ M., Standardy dobrej administracji, Poznań 2017.

Rabska T., „Norma zadaniowa” w świetle publicznego prawa gospodarczego, [w:] W poszukiwaniu dobra wspólnego. Ksiegga jubileuszowa Profesora Macieja Zielińskiego, red. A. Chodun, S. Czepita, Szczecin 2010.

Rabska T., Jakie prawo gospodarcze? — próba odpowiedzi, „Ruch Prawniczy, Ekonomiczny i Socjologiczny" 1993, nr 1.

Rabska T., Publiczne prawo gospodarcze - na przełomie?, [w:] Nowe problemy badawcze w teorii publicznego prawa gospodarczego (z uwzględnieniem samorzadu terytorialnego), red. L. Kieres, Wrocław 2010.

Rabska T., Zadania administracji publicznej w działalności gospodarczej (problem zakresu obowiazywania prawa działalności gospodarczej), „Ruch Prawniczy, Ekonomiczny i Socjologiczny” 2002 , $\mathrm{nr} 2$.

Strzyczkowski K., Prawo gospodarcze publiczne, Warszawa 2011.

Tarno J.P., Funkcje zasad ogólnych postępowania administracyjnego, [w:] Zasady ogólne postęowania administracyjnego, t. 2, cz. 2, red. G. Łaszczyca, A. Matan, Warszawa 2018.

Wróblewski J., Teoretyczne zagadnienia standardów w prawodawstwie w stosowaniu prawa, „Ruch Prawniczy, Ekonomiczny i Socjologiczny" 1989, nr 3. 
Zdyb M., Podstawowe zasady (standardy) tadu gospodarczego w świetle ustawy z 6.3.2018 r. Prawo przedsiębiorców, „Monitor Prawniczy” 2018, nr 13, dodatek.

Ziemski K., Zasady ogólne prawa administracyjnego, Poznań 1989.

Zimmermann J., Prawo administracyjne, Warszawa 2016.

\section{Unavoidability of standards of "good administration" in public economic law}

\section{Summary}

The Act of 6 March 2018 - Law of Entrepreneurs, contains a wide catalogue of provisions, mainly procedural in nature, referring to the general principles regulated in the Code of Administrative Procedure, treated as a model of "good administration". The legal principles included in the Law of Entrepreneurs concerning the operation of public administration have a wider scope of application than the matters of undertaking, conducting and terminating economic activity. They can be regarded as general (procedural) principles, i.e. important for the entire order of public economic law, not only in the sphere of state tasks related to undertaking, conducting and terminating economic activity.

Keywords: good administration, Law of Entrepreneurs, public economic law. 